\title{
MICROPROPAGATION OF MERREMIA QUINQUEFOLIA (L.) HALLIER F. FROM NODAL EXPLANTS
}

\author{
Short communication \\ Mafatlal M. KHER, M. NATARAJ*, Hettal D. PARMAR, Hasmatbanu BUCHAD \\ B.R. Doshi School of Biosciences, Sardar Patel University \\ Sardar Patel Maidan, Vadtal Road, Post Box No. 39, Vallabh Vidyanagar-388120, Gujarat, India \\ Received: February, 2015; Accepted: May, 2015 \\ Edited by M. Podwyszyńska
}

\begin{abstract}
Merremia quinquefolia, is an important medicinal plant of the family Convolvulaceae known for its vasoconstrictor, uterotonic, neurohormonic, sympathicolytic and sedative effects. In the present investigation effect of cytokinins 6-benzylaminopurine (BAP), kinetin (Kn) and thidiazuron (TDZ), at concentrations 1.0, 2.0, 3.0, 4.0 and $5.0 \mathrm{mg} \cdot \mathrm{dm}^{-3}$ on in vitro shoot multiplication from nodal explants of $M$. quinquefolia was evaluated. Bud breaking and emergence of shoots started within 10-15 days of inoculation in all media containing cytokinin. Murashige and Skoog (MS) medium supplemented with $4.0 \mathrm{mg} \cdot \mathrm{dm}^{-3}$ BAP resulted in maximum number of shoots from single node within 45 days. In vitro raised shoots were successfully rooted on $1 / 2$ mineral salts of MS medium with $3 \%$ sucrose supplemented with $2.0 \mathrm{mg} \cdot \mathrm{dm}^{-3}$ indole3-butyric acid (IBA). This is the first report on in vitro propagation of Merremia quinquefolia. This study can be useful for development of micropropagation protocols for related taxa.
\end{abstract}

Key words: axillary shoot multiplication, Convolvulaceae, Merremia quinquefolia

\section{INTRODUCTION}

Merremia is a genus of the family Convolvulaceae. According to The Plant List (2015), 54 species of Merremia are reported around the world), and are distributed in tropical region of Africa, Asia, Australia, North and South America, and China (Simpson 2015). In India M. quinquefolia is distributed in Maharastra, Gujarat, Orisa and Rajasthan (Khare 2007). Seeds of M. quinquefolia contain ergoline alkaloids that are reported to produce vasoconstrictor, uterotonic, neurohormonic, sympathicolytic and sedative effects (Khare 2007). M. quinquefolia is an herbaceous climber characterized by palmately compound leaves, white flowers and with straw colored globose capsules having brown black seeds (Rao \& Safui 1963). M. quinquefolia is used as diuretic, deobstruent, antirheumatic and alterative; the root is used as mouthwash; leaves are used for burns, scalds and sores (Khare 2007).
Antibacterial activity of M. emarginata was reported by Elumalai et al. (2011), and antidiabetic activity by Arunachalam and Parimelazhagan (2012). Merresectine alkaloid was isolated from $M$. dissecta root (Weigl et al. 1992). M. quinquefolia is cultivated at commercial scale for medicinal purposes in West Africa (Quiroz et al. 2014).

Plant tissue culture techniques are used for in situ conservation of many medicinally important plants (Bharvad \& Mohan 2012; Inamdar et al. 1990; Kher et al. 2014; Mehta \& Subramanian 2005; Sharma \& Mohan 2006a, b; Sharma et al. 2007; Varghese et al. 1993a, b, 1992). Axillary shoot proliferation technique is popularly used for clonal propagation in order to produce true to type and a high quality plants. Micropropagation and genetic transformation using tissue culture technique was reported in other Convolvulaceae genera including sweet potato (Ipomoea batatas) (AfreenZobayed et al. 2000; El Abidine Triqui et al. 2008; 
Yang et al. 2011) and M. tridentata (Kaladhar 2010). In the present paper results from study of plant growth regulators influence on in vitro shoot multiplication from nodal explants of M. quinquefolia and on in vitro rooting of raised shoots are presented.

\section{MATERIALS AND METHODS}

Nodal explants were taken from healthy M. quinquefolia plant from nearby BRD School of Biosciences campus, Sardar Patel University. The explants were washed thoroughly with running tap water for $30 \mathrm{~min}$, and then treated with $3 \%$ Neutral Rankleen detergent (v/v) (RFCL - India) for $10 \mathrm{~min}$ followed by 30 minutes washing in tap water. Thereafter the explants were sterilized with $0.1 \%$ mercuric chloride (w/v) solution for 3 minutes and then rinsed 3-4 times with sterile distilled water (DW).

Murashige and Skoog - MS medium (Murashige \& Skoog 1962) supplemented with 3\% (w/v) sucrose and $0.8 \%(\mathrm{w} / \mathrm{v})$ plant tissue culture grade agar (Merck, India) was used throughout the experiments. The $\mathrm{pH}$ of the medium was adjusted to 5.8. All the cultures were maintained at $25 \pm 2{ }^{\circ} \mathrm{C}$ under 16 hours photoperiod with a photosynthetic photon flux density (PPFD) of $35 \mu \mathrm{mol} \cdot \mathrm{m}^{-2} \cdot \mathrm{s}^{-1}$ provided by cool white florescent tubes ( $36 \mathrm{~W}$, Philips, India).

To study the effect of cytokinin 6-benzylaminopurine (BAP), kinetin (Kn) and thidiazuron (TDZ) of concentration $1.0,2.0,3.0,4.0$ and $5.0 \mathrm{mg} \cdot \mathrm{dm}^{-3}$ on shoot bud formation, nodal explants were cultured on $20 \mathrm{ml}$ medium in borosilicate glass test tube ( 25 $\times 150 \mathrm{~mm}$ ). In vitro raised shoots of 3-4 cm length were divided for single node explants and routinely cultured on MS medium supplemented with $4.0 \mathrm{mg} \cdot \mathrm{dm}^{-3} \mathrm{BA}$ for one month in borosilicate glass bottles of $400 \mathrm{ml}$ capacity with $50 \mathrm{ml}$ of medium.

The shoots of $4-5 \mathrm{~cm}$ in length raised from this medium were transferred to $1 / 2$ mineral MS salts with 3\% sucrose, and supplemented with indole-3acetic acid (IAA) or indole-3-butyric acid (IBA) at concentrations $0.5,1.0,1.5$ and $2.0 \mathrm{mg} \cdot \mathrm{dm}^{-3}$ to optimize rooting conditions.

Experiments having 12 replicates (explants) per treatment were repeated at least three times. Observations from all experiment were recorded after 45 days. Mean values were subjected to one way analysis of variance (ANOVA) using SPSS Inc., Chicago, USA. The significance of difference among mean values was carried out using Duncan's multiple range test (DMRT) at $\mathrm{p}<0.05$.

\section{RESULTS AND DISCUSSION}

There is no report available on tissue culture studies on $M$. quinquefolia, and only two reports on in vitro responses of entire Merremia genus concerning excised embryo reaction of $M$. dissecta to inositol (Sankhla et al. 1966) and callus mediated regeneration from shoot tips and floral explants of M. tridentata (Kaladhar 2010). It is well accepted that more chances of getting somaclonal variations is in callus mediated organogenesis (Bairu et al. 2011). Therefore axillary shoot multiplication is popular choice, however callus mediated organogenesis can be used for genetic transformation studies.

The response of nodal explants cultured on MS medium supplemented with various concentrations of 6-benzylaminopurine (BAP), kinetin (Kn) and thidiazuron (TDZ) is presented in Table 1. Nodal explants showed minimal response in the cytokinin free medium, where only $12.5 \%$ of nodal explants produced average 1.8 shoots per node. MS medium supplemented with TDZ, Kn and BAP caused bud breaking within 10-15 days of inoculation (Fig. 1A). In the medium supplemented with $5.0 \mathrm{mg} \cdot \mathrm{dm}^{-3}$ TDZ, $58.3 \%$ of cultures responded with average 4.5 shoots per node, on the medium supplemented with $5.0 \mathrm{mg} \cdot \mathrm{dm}^{-3} \mathrm{Kn}$, average 3.6 shoots per node was obtained in $62.5 \%$ of cultures, and $70.8 \%$ cultures were produced average 6.11 shoots per node on the medium supplemented with $4.0 \mathrm{mg} \cdot \mathrm{dm}^{-3}$ BAP (Fig. 1B) within 45 days. Propagation from nodal explants of a sweet potato Ipomoea tuberculata 'Carmen Rubin' and 'White Triumph', a plant of the same family, was recommended on MS medium supplemented with 1 and $0.1 \mathrm{mg} \cdot \mathrm{dm}^{-3} \mathrm{Kn}$ and rooting on $0.5 \mathrm{mg} \cdot \mathrm{dm}^{-3}$ of IAA (Doliński \& Olek 2013). The variation in requirement of cytokinin type and concentration differs between plant species, genotypes, cultivars and explant types. Therefore it is essential to optimize plant growth regulator type and concentration for successful establishment of micropropagation protocol for any plant species. 

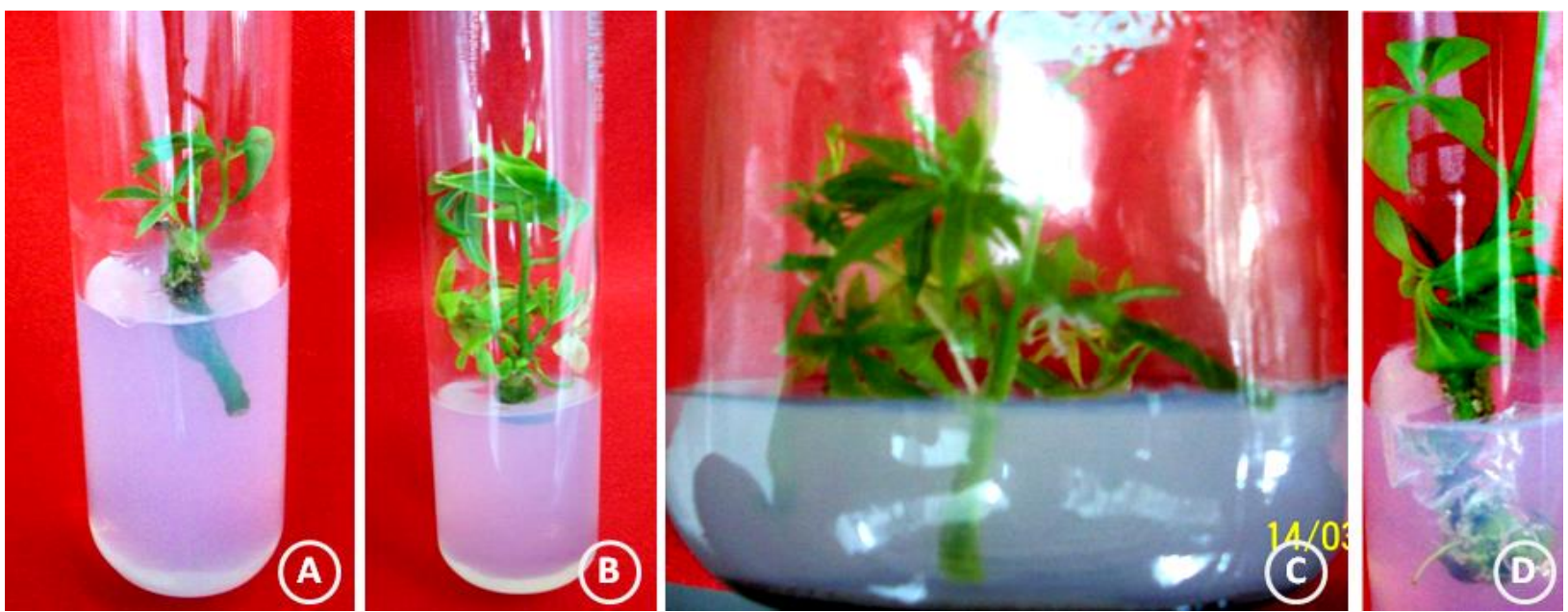

A - Culture initiation after 15 days; B - Elongated shoots after 45 days;

C - Culture multiplication after 45 days; D - Rooting of shoots

Fig. 1. Stages of micropropagation from culture initiation to rooting of $M$. quinquefolia

Table 1. Effects of type and concentrations of cytokinin on shoot multiplication on nodal explants of $M$. quinquefolia evaluated after 45 days

\begin{tabular}{lccl}
\hline Cytokinin & $\mathrm{mg} \cdot \mathrm{dm}^{-3}$ & $\begin{array}{c}\text { \% of node re- } \\
\text { sponse }\end{array}$ & $\begin{array}{c}\text { Shoot number } \\
\text { per node }\end{array}$ \\
\hline Control & 0.0 & 12.5 & $1.8 \pm 0.50^{\mathrm{h}}$ \\
TDZ & 1.0 & 25.0 & $3.0 \pm 0.89^{\mathrm{gh}}$ \\
TDZ & 2.0 & 33.3 & $2.6 \pm 0.91^{\mathrm{gh}}$ \\
TDZ & 3.0 & 45.8 & $3.2 \pm 1.00^{\mathrm{efg}}$ \\
TDZ & 4.0 & 50.0 & $4.0 \pm 1.50^{\mathrm{cdefg}}$ \\
TDZ & 5.0 & 58.3 & $4.5 \pm 1.60^{\mathrm{bcdef}}$ \\
Kn & 1.0 & 37.5 & $2.9 \pm 1.16^{\mathrm{gh}}$ \\
Kn & 2.0 & 45.8 & $3.0 \pm 1.13^{\mathrm{fgh}}$ \\
Kn & 3.0 & 54.1 & $3.3 \pm 1.31^{\mathrm{efg}}$ \\
Kn & 4.0 & 58.3 & $3.4 \pm 1.50^{\mathrm{efg}}$ \\
Kn & 5.0 & 62.5 & $3.6 \pm 1.40^{\mathrm{defg}}$ \\
BAP & 1.0 & 54.1 & $4.6 \pm 1.70^{\mathrm{bcde}}$ \\
BAP & 2.0 & 58.3 & $5.8 \pm 1.71^{\mathrm{ab}}$ \\
BAP & 3.0 & 66.6 & $4.9 \pm 1.43^{\mathrm{bcd}}$ \\
BAP & 4.0 & 70.8 & $6.1 \pm 1.50^{\mathrm{a}}$ \\
BAP & 5.0 & 79.1 & $5.3 \pm 1.60^{\mathrm{abc}}$ \\
\hline
\end{tabular}

Means \pm SD in each column followed by same letters at superscripts are not significantly different at $p<0.05$ according to DMRT $(\mathrm{n}=$ minimum 12 replicates). Experiment was repeated thrice.

In vitro raised shoots (Fig. 1C) were successfully rooted on $1 / 2$ strength MS medium but number of roots depended on type and concentration of auxin. 1-2 tap roots were produced on auxin free medium (Fig. 1D). There were no differences in rooting on the media containing $0.5 \mathrm{mg} \cdot \mathrm{dm}^{-3}$ IAA or IBA. The medium supplemented with $2 \mathrm{mg} \cdot \mathrm{dm}^{-3}$
IBA yielded maximum number of roots per shoots although no statistical differences were between media supplemented with $1.5,2.0$ and $2.5 \mathrm{mg} \cdot \mathrm{dm}^{-3}$ IBA or 1.5 and $2 \mathrm{mg} \cdot \mathrm{dm}^{-3}$ IAA (Fig. 2). Kaladhar (2010) investigated auxin IAA at $0.1,0.3,0.5,1.0$, 2.0 and $3.0 \mathrm{mg} \cdot \mathrm{dm}^{-3}$ and found that $1 \mathrm{mg} \cdot \mathrm{dm}^{-3} \mathrm{re}-$ sulted in formation of roots in $85 \%$ cultures of M. tridentata. This study can be useful for development of micropropagation protocols for related taxa.

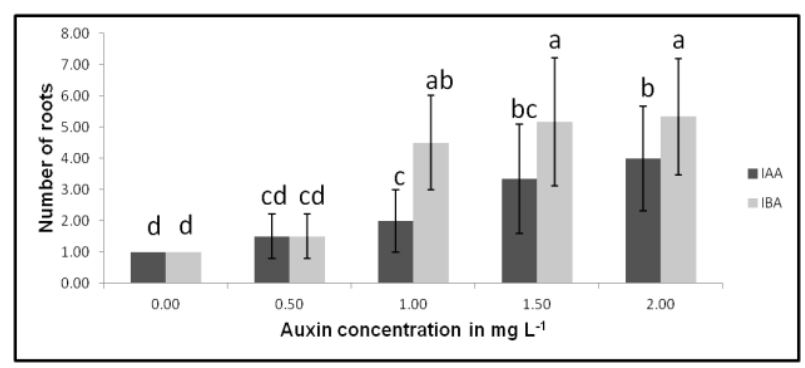

Fig. 2. Effect of concentration of auxins on in vitro rooting of M. quinquefolia as evaluated after 45 days. Bars represent means $\pm \mathrm{SE}(\mathrm{n}=12)$ repeated thrice. The same letters show means that are not significantly different at $<0.05$ according to DMRT

\section{Acknowledgement}

We are thankful to Head of the department BRD School of Biosciences, Sardar Patel University, Vallabh Vidyanagar for research support, Dr. A.S. Reddy from BRD School of Biosciences, Sardar Patel University for Identification of the plant and Dr. Sandip L. Patel for the collection of plant materials and Dr. Vinay R. Patel for photography assistance. 


\section{REFERENCES}

Afreen-Zobayed F., Zobayed S., Kubota C., Kozai T., Hasegawa O. 2000. A combination of vermiculite and paper pulp supporting material for the photoautotrophic micropropagation of sweet potato. Plant Science 157: 225-231. DOI: 10.1016/S0168-9452(00)00288-0.

Arunachalam K., Parimelazhagan T. 2012. Antidiabetic activity of aqueous root extract of Merremia tridentata (L.) Hall. f. in streptozotocin-induced-diabetic rats. Asian Pacific Journal of Tropical Medicine 5: 175 179. DOI: 10.1016/s1995-7645(12)60020-0.

Bairu M.W., Aremu A.O., van Staden J. 2011. Somaclonal variation in plants: causes and detection methods. Plant Growth Regulation 63: 147173. DOI: $10.1007 / \mathrm{s} 10725-010-9554-x$.

Bharvad P.B., Mohan J.S.S. 2012. In vitro propagation of a rare medicinal herb: Schweinfurthia papilionacea A. Br. Indian Journal of Biotechnology 11: 476-480.

Doliński R., Olek A. 2013. Micropropagation of sweet potato (Ipomoea batatas L. Lam) from node explants. Acta Scientiarum Polonorum, Hortorum Cultus 12: 117-127.

El Abidine Triqui Z., Guédira A., Chlyah A., Chlyah H., Souvannavong V., Haïcour R., Sihachakr D. 2008. Effect of genotype, gelling agent, and auxin on the induction of somatic embryogenesis in sweet potato (Ipomoea batatas Lam.). Comptes Rendus Biologies 331: 198-205. DOI: 10.1016/j.crvi.2007.11.009.

Elumalai E., Ramachandran M., Thirumalai T., Vinothkumar P. 2011. Antibacterial activity of various leaf extracts of Merremia emarginata. Asian Pacific Journal of Tropical Biomedicine 1: 406408. DOI: 10.1016/S2221-1691(11)60089-0.

Inamdar J.A., Nataraj M., Mohan J.S.S., Subramanian R.B. 1990. Somatic embryogenesis from callus cultures of Crataeva nurvala Buch. Ham. Phytomorphology 40: 319-322.

Kaladhar D.S.V.G.K. 2010. In vitro regeneration of the medicinal herb, Merremia tridenteta L. from shoot tip and flower explants. Journal of Biochemistry and Biotechnology 1: 65-71.

Khare C.P. (Ed.) 2007. Merremia quinquefolia. In: Indian medicinal plants: An illustrated dictionary. Springer, New York. DOI: 10.1007/978-0-387-70638-2.

Kher M.M., Joshi D., Nekkala S., Nataraj M., Raykundaliya D.P. 2014. Micropropagation of Pluchea lanceolata (Oliver \& Hiern.) using nodal explant. Journal of Horticultural Research 22: 35-39. DOI: 10.2478/johr-2014-0004.

Mehta S., Subramanian R. 2005. Direct in vitro propagation of Asparagus adscendens Roxb. Plant Tissue Culture 15: 25-32.

Murashige T., Skoog F. 1962. A revised medium for rapid growth and bio assays with tobacco tissue cultures. Physiologia Plantarum 15: 473-497. DOI: 10.1111/j.1399-3054.1962.tb08052.x.
Quiroz D., Towns A., Legba S.I., Swier J., Brière S., Sosef M., van Andel T. 2014. Quantifying the domestic market in herbal medicine in Benin, West Africa. Journal of Ethnopharmacology 151: 11001108. DOI: 10.1016/j.jep.2013.12.019.

Rao T.A., Safui B. 1963. Distribution of some rare plants along Saurashtra coast and neighbouring Islands. Proceedings of the Indian Academy of Sciences Section B 58: 362-366. DOI: 10.1007/BF03051966.

Sankhla N., Chatterji U.N., Baxi D. 1966. In vitro response of excised embryos of Merremia dissecta (Jacq.) Hallier f. to inosital. Naturwissenschaften 53: 334. DOI: 10.1007/BF00631203.

Sharma U., Mohan J.S.S. 2006a. In vitro clonal propagation of Chlorophytum borivilianum Sant. et Fernand., a rare medicinal herb from immature floral buds along with inflorescence axis. Indian Journal of Experimental Biology 44: 77-82.

Sharma U., Mohan J.S.S. 2006b. Reduction of vitrification in in vitro raised shoots of Chlorophytum borivilianum Sant. \& Fernand., a rare potent medicinal herb. Indian Journal of Experimental Biology 44: 499-505.

Sharma U., Rao V.R., Mohan J.S.S., Reddy A.S. 2007. In vitro propagation of Dendrobium microbulbon A. Rich - a rare ethnomedicinal herb. Indian Journal of Biotechnology 6: 381-384.

Simpson D. 2015. Merremia quinquefolia (L.) Hallier f. 1893. www.somemagneticislandplants.com.au/index.php/plants/387-merremia-quinquefolia (accessed 12.03.15)

The Plant List 2015. Merremia quinquefolia (L.) Hallier f. www.theplantlist.org/tpl1.1/record/tro8500795 (accessed 12.03.15)

Varghese S.K., Inamdar J.A., Kalia K., Subramanian R.B., Nataraj M. 1993a. Micropropagation of Aegle marmelos (L.) Corr. Phytomorphology 43: 87-92.

Varghese S.K., Inamdar J.A., Kalia K., Subramanian R.B., Nataraj M. 1993b. In vitro organogenesis in Enicostema hyssopifolium (Willd) Verdoon. Proceedings of the National Academy of Sciences, India-Section B 63: 219-221.

Varghese S.K., Subramanian R.B., Nataraj M., Kalia K., Inamdar J.A. 1992. In vitro studies on Vitex negundo. Indian Botanical Contactor 9: 147-150.

Weigl R., Kaloga M., Eich E. 1992. Merresectines: novel tropane alkaloids from Merremia dissecta roots. Planta Medica 58: 705-706. DOI: 10.1055/s-2006-961731.

Yang J., Bi H.-P., Fan W.-J., Zhang M., Wang H.-X., Zhang P. 2011. Efficient embryogenic suspension culturing and rapid transformation of a range of elite genotypes of sweet potato (Ipomoea batatas (L.) Lam.). Plant Science 181: 701-711. DOI: 10.1016/j.plantsci.2011.01.005. 